\title{
Autonomy Necessary but not Sufficient: Comparative Study of CFM, Nepal and JFM, India
}

- Rucha Gbate* and Suresh Ghate**

"Researcher, SHODH: The Institute for Research and Development, 106, K.T. Nagar, Nagpur-440013, India, ${ }^{* *}$ Reader, Post Graduate Teaching Department of Mathematics, RTM Nagpur University Nagpur - 440033, India,

Corresponding author: ruchaghate@gmail.com

Abstract: 'Autonomy' to local users is widely discussed and considered a necessary attribute to form and effectively function self-governing associations in common pool resources. Especially when the resource is local in scale, autonomy to local users can ensure good governance on the ground so locals are better equipped in developing effective institutions. This article compares varying degrees of autonomy to forest dwelling communities and its effect in decentralized forest management in two countries - Nepal and India. Comparison is made by using data collected from revisits of 6 IFRI sites from each country, after creating indices for functional autonomy, institutional functioning, forest quality, and forest dependence of the respective communities. The paper concludes that extending autonomy to communities is not enough; rather autonomy needs to be functional. Also, forming and putting institutions in place may not lead to improvement in forest quality and forest product availability. The in place may not lead to improvement in forest quality and forest product availability. The newly created institutions need sufficient investment to make them robust, for which positive and proactive intervention by various agencies is essential.

Key words: functional autonomy, institutions, forest, local users, IFRI data.

\section{INTRODUCTION}

In the quest of finding the necessary conditions for managing common pool resources, the issue of 'autonomy' to local users seems to be coming up time and again. Autonomy is one of the attributes of appropriators on which considerable consensus exists regarding its importance for self-governing associations to form and function effectively (Ostrom 1990, 2005; Agrawal and Gupta 2005; Acheson et al. 2004; Ostrom and Nagendra 2006). The case for increased administrative and political decentralization is strengthened by the observation that long enduring institutions are characterized by those that allow resource users to devise their own rules governing the institutions (Esmail 1997). In contrast, under centralized regimes, local resource users would not invest their time and resources in changing the rules, nor would the centralized regimes be able to address locally relevant issues. Therefore, when local users do not exercise significant control over collective and constitutional-leve choices related to rule design, management, and enforcement, the impact of decentralization is limited (Agrawal and Ostrom 2001).

Two essential conditions that cause individuals to construct institutions for managing natural resources are salience and perceived scarcity (Gibson et al. 2007). Yet, without autonomy it would be costly to implement the rules even if devised by local organization, and would prove to be a deterrent. In cases where autonomy is not formally recognised, those who disagree with locally developed rules could seek contacts with higher-level officials to undo the efforts of users to achieve regulation. With the legal autonomy to make their own rules, users face substantially lower costs in defending these rules against other authorities (Ostrom 1998; Ghate 
2000). Communities need authority to set boundaries and control access to the resource, to monitor rule violations, and to enforce sanctions. However, rules need to be workable in terms of local ideas and resources (Burns and Burns 2004)

Autonomy to local users is important for achieving good governance of natural resources as local users are better equipped in developing effective institution especially when the resource is local in scale (Regmi 2008). In a study Regmi (2008) conducted in Nepal, the performance of Farmer Managed Irrigation System (FMIS) was better than the government agency managed irrigation system because in the FMIS case, the farmers i.e. the local users, were given complete autonomy to devise their own rules suiting their local conditions. Likewise, in a study of how local governance has influenced the forest conditions in the Mpigi District of Uganda, Banana et al. (2004) stated that with decentralization, forests did not improve because devolution of rights and responsibilities over the forests to the local government was only partial.

Contrastingly, in case of Niger, the government extended extensive local autonomy under its "rural wood-energy markets" program. This did not impose technical solutions, but promoted the emergence of possible solutions through encountering of challenges and selforganization. The process resulted some 150,000 ha of forest under management, appropriate quotas and harvesting techniques, high tax collection rates, increased incomes for local populations, and increased levels of social investments (Anderson 2000).

Given the variation in forest management with degree of autonomy, it is pertinent to question if the existence of autonomy is enough to ensure good management of common pool resource like forest. Or, is there a need for good institutions to make 'autonomy' functional? In this article, we discuss this question in the context of two the countries, Nepal and India that have adopted decentralized forest management methods with varying degrees of autonomy given to communities. While Nepal adopted Community Forestry, initially in the form of Panchayat Forest in 1978, Joint Forest Management (JFM) was introduced in India only in 1990. Since then community forestry in Nepal has been recognized as the 'best practice in participatory forestry', where local people are genuinely in control of management of forest resources (Taylor 1993 as quoted in Pokharel et al. 2007). Is the situation very different in India? How are the policies and practices different in the two neighbouring countries? How functional is the autonomy, and how is it impacting institutional functioning, forest health and people's dependence on the resource? 'These are the questions addressed here with the help of data collected from six sites that have been revisited with a gap of at least five years, both in Nepal and India, using the same methodology.

We first briefly discuss the history of decentralization in Nepal and India, bringing out similarities and differences at policy level, and then analyse data collected using International Forestry Research and Institutions (IFRI) protocols.

\section{EVOLUTION OF COMMUNITY} FORESTRY IN NEPAL

Decentralisation of forest managemen authority in Nepal has largely emerged due to the failure of centralised forest management system to manage forest resources as per the needs of nation and local people (Adhikari et al. 2003). This devolution of autonomy to the local people emerged from the changes in the forest policy in the last five decades. Traditionally, despite the ownership resting with the government, communities limited overexploiting their forests and crafted informal rules directly governing resource management 
including resource use. However, increase in population, inconsistent forest policy, and subsequent nationalization of forests led to large scale reduction and degradation of forest (Adhikari 2006). As a consequence, the community level institutions (i.e. customary laws), which are used to guide all matters relating to the economy and society of communities, gradually lost their credibility.

The Forest Act 1961, which was focused on forest administration, strengthened the Forest Department's ownership of forest lands. According to this Act, forest was divided into different categories, and authority and responsibilities of forest department were defined (Gautam et al. 2004). Furthermore, in 1967 the Forest Preservation Act was introduced which described penalties and offences that would be imposed on illegal activities in the national forest. However, due to a poorly staffed forest department, the act was not properly implemented, and the villagers largely ignored it, due to which deforestation continued on. Thus, none of the Acts were able to reach the desired aim of halting deforestation in the country. According to Gautam et al.2004, the Acts were mainly concerned with the sale of forest products, prohibition, punishment and organisational changes rather than sustainable management and long term planning.

In 1976, a draft national forestry plan was prepared as a result of the Ninth Forestry Conference held in Kathmandu in 1974, wherein it was emphasised that forests would be in better condition under the control of local communities rather than the government. Following this, forests were re-categorised in 1978 into Panchayat (a local level unit) Forest (PF), Panchayat Protected Forest (PPF), Private Forest, Leasehold Forest, Religious Forest, and Government Forest. The amended Act was largely meant to assign responsibilities and rights over forests to the local political bodies. However, this decentralisation initiative of the
Government was still not implemented in its true sense. Participatory forestry was still restricted to government projects, and the people did not have autonomy over the decisions. In many cases, elite capture was common in the Panchayat system. It was only after the preparation of the 25 year Master Plan for the forestry sector during 1986-88 and later amended in 1989 (Gautam 2004), that the final decision was taken to hand over forests to groups of traditional forest users (Kanel 2008) Emphasis of this plan was on setting up of Forest User Groups for the management, protection and sustainable utilisation of the forests. Later in 1993, amendments to the Master Plan were made which led to the formulation of the Forest Act 1993, and Forest Regulations in 1995. According to this Act forests were categorised into Community Forests, Leasehold Forest, Government Managed Forest, Religious Forest, and Protected Forest. The focus of this act was institutionalisation of the Community Forest User Group (CFUG) as an independent and self governing entity with complete utilisation and management rights (Kanel 2008). This could be regarded as the turning point in the history of Forest Policy in Nepal.

According to Kanel (2008), "the devolution of autonomy over forest management to the local people has enabled communities to co-ordinate their collective activities resulting in better resource management". At present there are over 14000 CFUGs scattered throughout Nepal. Evidence from micro-level studies shows improvements in forest conditions since the devolution of forest management to CFUGs (Kanel 2008). However, there are some studies that have indicated unequal distribution of benefits accruing from community management. Khatri Chhetri (2008) indicates that the contribution of forest products to household income is higher in forest management without formal institution than 
with formal institution. His analysis also indicated the burden of conservation falls on poorer households since the access and conservation rules imposed on them by formal user groups do not fulfill their needs of forest products. Similarly, there are some critical problems with CFUGs's pro-poor programs aimed to reduce poverty through the resources generated from community forestry. A study by Pokharel (2008) reports that though timber is subsidized, the subsidies accrue mainly to the non-poor. Also, income spent on loans tends to favor the non-poor as some $74 \%$ of the benefits of community forestry funds accrue to the non-poor while $26 \%$ accrue to the poor in rural communities in Nepal.

\section{EVOLUTION OF JOINT FOREST}

\section{MANAGEMENT IN INDIA}

Forest Policy in India has undergone significant changes over the past 118 years. The first two forest policies (1894 and 1952), as reflected in the Indian Forest Act 1927, resulted in derecognition of communal property (Guha 1983); with restrictions on forest dwellers on collection of forest products, and some concessions on forest use in return of obligation to help the Forest Department (Joshi 1983). Social forestry - a program that was designed to increase supply of fuel wood and fodder for communities, in reality resulted into increased supply of industrial wood, and excluded the traditional role of the community participation (Shiva et al. 1983). Following quote sums up the view on the implementation of forest policies before 1988:

"Far from being of immediate benefit to the primitive tribes, the establishment of British rule in India did most of them much harm than good. It may be said that the early days of British administration did very great detriment to the economic position of tribes through ignorance and neglect of their rights and custom" (Hutton as quoted in the Report of SC and ST Commission, 1960-61)
Decentralization of forest management began ever since the acceptance of people oriented forest policy, the National Forest Policy 1988, which brought a complete paradigm shift visà-vis the earlier two policies. Although the major emphasis remained on the ecological roles of forests, domestic requirements of fuelwood, fodder, minor forest produce, and construction timber for local communities were accepted to be the first charge on forest produce. At the same time, the policy expressed the need to "associate the tribal people closely in the protection, regeneration and development of forests as well as provide employment to people living in and around forests". Joint Forest Management (JFM) approach was based on this policy.

JFM envisages building of village-level institutions, more popularly named as Forest Protection Committees (FPC). In a recent move, the central Government has encouraged federation of JFM/FPC under Forest Development Agencies (FDA) to strengthen the JFM committees. Offering better livelihood opportunities through integration of development programs of other government agencies to deal with rural poverty is an extended objective of the FDA. This seems to be in keeping with what Gibson et al. (2005) have to say, "No matter how well-intentioned those providing assistance are, or how many resources are transferred, development will occur only if political and economic institutions generate incentives that facilitate individual's achievement of development goals". While the process of decentralisation of forest management was extended through subsequent legislations, like The Panchayat Extension to Scheduled Areas Act (PESA) of 1996 that gave power to the gram sabha (village assemblies) in scheduled areas over community resources, especially over minor forest products; and the recent passing of 'Scheduled Tribes and other Traditional Forest Dwellers (Recognition of Forest Rights) 
Act, 2006, there was simultaneous effort to dependence on forests is reduced to non-timber centrally control ownership of forests through forest products, small timber, firewood for legislations like the Forest Conservation Act, domestic use, and indirect benefits.

1980 (amended in 1988).

Over the last two decades, many evaluationbased studies have been published discussing various aspects of the JFM program. The studies demonstrate that in most places, protection committees created under the JFM do not last long, or end being unequal partners (Matta and Kerr 2004). They become dysfunctional either after initial enthusiasm dies down or after the incentive money is exhausted (Kumar 2002). In some cases, village level JFM committees exist only on paper, and are ineffective in protecting the resource (Ghate and Nagendra 2005). Some note that communities by and large have remained unconvinced about the benefits to be gained from accepting the state designed arrangements at considerable loss of autonomy, while there are also concerns over the state's covert attempts to expand its authority over forests (Sarin et al. 2003), leaving no room for people's participation (Ballabh et al. 2002). It is alleged that, forest officials have no real interest in the community and, thus, in 'collective action' (Hill 2000), and some find participation by local communities as 'puppetish' (Lele 2000), indicating that it is not 'participation' in true sense.

Upadhyaya (2003) feels that JFM continues on weak legal footing as it fails to ensure security of rights. He feels that the short-term benefits offered under JFM do not act as additional incentives because they are no different from the nistar rights that were enjoyed by the communities before JFM. Studies have also indicated that legislation is not enough to ensure participation (Puri 2004). Kaushal and Kala (2004) states that in the long-term, success of JFM appears doubtful unless people's

India and Nepal seem to have similar backgrounds while entering the decentralization era. Conventional forest management through Forest Department had not worked well until 1980s, as was evident in continuous increase in the rates of deforestation. Devolution was expected to reverse this trend, and at the same time address the issue of poverty pervading amongst the forest dependent communities in both the countries.

\section{METHODOLOGY}

The study is based on the primary data collected by Collaborative Research Centres (CRCs) in Nepal and India. CRCs collect data through a set of ten structured protocols, making the data collected from different sites and at different points of time, comparable. The questions in the protocols collect quantitative as well as qualitative information. In this study, we have selected six sites, each from Nepal (Raniswara, Barbote, Khareha, Danapur, Chandraban, and Thoplebrian) and India (Saigata, Lakhapur, Mendha, Markegaon, Ranvahi and Deulgaon), data for which was collected more than once, with a gap of at least five years. In case of Nepal, some sites were visited more than twice. In such cases, we have used the data of last two visits. Data from all the sites has been collected between 1997 and $2008^{* * *}$. Availability of revisited sites has provided rare opportunity to analyse the data that has been collected from the same sites, using same methodology, making the comparison more robust.

As the institutions are in place (under the aegis of CFM and JFM) with a certain level of autonomy to local communities in both

For details refer to Ghate, R. and S. Ghate. 2010. Autonomy not enough: Good Institutions are necessary too. A comparative study of CFM, Nepal and JFM, India. IFRI Working Paper No. W10I-01. International Forestry Resources and Institutions Program. Ann ArborM I 
countries, this study focused on four aspects namely, autonomy, institutional functioning, forest quality, and forest dependence that emerge from the IFRI data collection. To make the comparison possible, relevant questions were identified, followed by quantification in terms of indices created by converting text answers to ranked numeric values. On the issue of autonomy, it was desired to measure how functional the autonomy was by considering responses on how autonomy gets reflected on real ground. From the IFRI data base, it was clear that this could be captured through the five variables, namely - designation of the forest, units of management, authority deciding penalty imposition, authority for collection of fine, and use of the amount collected as fine. The IFRI data base contains questions regarding management intervention by communities, rules framed (knowledge of rules, perception of rules as easy, clear, flexible, fair, legitimate, etc.), and participation (how members are elected, regularity of meetings, competition for positions, if members can be removed, attendance on the meetings, calling of special meetings, suggestions for rule change, and suggestions in allocation and their implementation). The dynamism of the institution was thus captured via the variables describing these issues of management, rules, and participation.

It is to be noted that IFRI has numerous questions which may seem to be related to autonomy and institutional functioning. However, the variables selected above were those that were appropriate for the South Asian situation. Further, out of many options for responses that were available for each of these indicators, only the relevant options were considered. In order to incorporate this change in options, these variables were renamed, and scores were assigned to capture progression. Basal area, Simpson biodiversity index, percentage of plots with evidence of erosion, number of species lost in past 5 years, and number of species lost in past 10 years were chosen to depict the forest quality. Forest dependence was determined by the percentage of user group's requirement fulfilled for fuel wood, fodder, timber, and food from their own forest. The forest-dependence index was obtained as the average of the above four percentages.

As mentioned above the overall institutional functioning was measured through three different aspects namely management related, rule related, and participation related. These three different aspects were denoted by three different indices. Quantification thus resulted into autonomy index, management index, rule index, participation index, and the forest dependence index.

Appendix 1 gives values of autonomy index management index, rule index, participation index and forest dependence index for all the sites along with maximum possible values of each of these indices.

\section{RESULTS}

Our study clearly indicates that forest institutions in Nepal have more autonomy than the forest institutions in India. For the first visit the mean of autonomy index for Nepal is 4.16 while for India is 3.0 . By the second visit, autonomy in Nepal has further enhanced as its mean rose to 4.83 , in contrast for India it remained stagnated at 3.0. This difference is statistically significant at $99 \%$ confidence level (See Appendix 3). However, in case of management it appears that Indian institutions were faring better (mean of Management index is 6.83) than their Nepali counterparts (5.33). But, in the second visit, forest institutions in Nepal have shown substantial improvement (8.83), while the Indian institutions have declined substantially (5.33). It must be mentioned though that the difference in management index for the two countries over 
the years are not statistically significant. In case of Nepal, of the six cases two have shown substantial improvement. There is a decline only in one case. On the other hand of the six cases in India, there is decline in five, one community Mendha, which had high management index, has more or less maintained it over the years. The community of Lakhapur had very high index of 15 in the first visit, which declined drastically to 8 in revisit. The community of Lakhapur was very aggressive in preserving its forest initially under the influence of a local socio-religious leader. After his death, the institution seems to have declined. As far as rule related aspects of institutions are concerned (clarity, fairness, flexibility, knowledge), there is hardly anything to differentiate the two countries over time. The institutions have fared well on this count and continue to do so. In case of Nepal, the mean of Rule index are 5.83, and 5.66 respectively for first and second visits. In case of India, the means are 5.5 and 5.83 respectively. Country wise and over time, differences are not statistically significant. On the aspect of participation, forest institutions in India initially fared slightly better than the institutions in Nepal. The picture changes by the second visit and the institutions in Nepal have improved substantially; while in case of India, the figures remain stagnant.

Overall, in terms of forest quality, forests in Nepal are better than those in India. Although the differences in case of basal area are not statistically significant, in case of Nepal, it has increased from 14.06 to 14.82 , and for India it has reduced from 13.34 to 12.11 (Appendix 2). As for Simpson index, it needs to be mentioned here that the forest types of the two countries are quite different due to elevation, temperature and soil type. Therefore, no comparison is made between the two countries, and over time biodiversity in both the countries has changed little (Nepal changed from 0.40 to 0.39 , and India from 0.102 to 0.109 ). However, the evidence of erosion clearly indicates degradation of forests in India (plots with erosion increasing from $5 \%$ to $86 \%$ in the two visits), while for Nepal, it is negligible. Similarly, while there are no species lost in Nepal, there are at least 8 species lost in the case of India (Appendix 2). These two are clear reflections on institutional functioning. Considering cumulative institutional index (management, rule making, and participation), there is decline in institutional functioning in India (from 17.6 to 16.4), Nepal has improved its performance on this count (from 15.9 to 20.5). More autonomy to local forest institutions in Nepal is the most probable reason for it

Communities in India substantially and increasingly depend on forest for their fodder, fuel wood, timber and food needs. The index of forest dependence in India has increased from 69 to 76, while in case of Nepal it has increased from 39 to 43. For fuel wood and timber, the communities in India have become completely dependent on forest, the dependence for fodder has only increased over the visits (from $81 \%$ to $93 \%$ ). In case of Nepal, the dependence is relatively low, but has slightly increased over the visits (Appendix 1).

From linear regression analysis, it is found that functional autonomy index increases at the rate of 1.167 (level of significance .01), and forest dependence decreases at the rate of 30.208 (level of significance .01) as the country variable changes from India to Nepal. In case of Nepal, there is a positive correlation of 0.550 (2-tailed level of significance of 0.064 ) between participation index and autonomy index. In case of India, there is a negative correlation of 0.714 (2-tailed level of significance of .01) between forest dependence and management index, and positive correlation of 0.585 (2-tailed level of significance of .05) between forest dependence and participation index. As far as the four indicators of institutional functioning are concerned, they are not correlated 
(statistically) significantly at all for Nepal or India. Thus these indices are changing over time and country, independently of each other.

\section{DISCUSSION}

Autonomy for the communities in making forest management decisions is important for both institutional functioning and improving forest quality. Explicit conviction in devolution has resulted in changing the designation of forests to 'community forest' in Nepal. In case of India, official designation remains either Reserved Forest or Protected Forest, and only some areas from these forests is demarcated for protection under JFM. Forest in Nepal has improved on all the five indicators and simultaneously, it is fulfilling higher percentage of fuel, fodder and timber requirements of the communities. This has not happened in case of India. Although dependence of communities on forest has increased in India, forest condition has worsened as reflected by the evidence of erosion and loss of species.

As Fisher (2000) notes, decentralization of forest management in India is of a type where governments seek public participation in potentially large-scale programs with centrallyset objectives, and where communities participate in government programs, receiving responsibility and some benefits, but little or no authority. Decentralization in Nepal involves handing over of significant amount of control to local communities, where community use rights to national forest can be formally recognized according to negotiated and approved management agreements. This difference in approach has reflected in the functional aspect of institutions. It is important to take into account the fact that the forest policies of both India and Nepal give authority to communities to take operational level decisions i.e. forming of rule structure, monitoring protection mechanism etc. Yet, considering the participation and management aspects of institutional functioning, institutions in Nepal are not only doing better than their Indian counterparts, but are also improving over time. This could be so because in case of Nepal, there is a legal provision for protecting, managing and utilizing forest and other resources as per decisions taken by their assemblies and according to their self prepared constitutions and operational plans with minimal scope for interference from the state forestry agency (Pokharel et al. 2007)****. This creates space for the local institutions to effectively function over time through experimentation and learning from past mistakes.

In case of India, the situation is not conducive for institutions to mature. The one-size-fits-all approach of the JFM, with its pre-packaged objectives and its narrow scope of forest management limits experimentation, learning, and institutional innovation that characterize community forest management (Nayak and Berkes 2008).

Although the data does not show statistically significant correlation between autonomy and working of the institutions and forest quality probably due to small sample size, it can be surmised from the data that in case of Nepal, there is simultaneous increase in functional autonomy and institutional functioning. The trend is opposite in India. A major conclusion of the paper is that extending autonomy to communities is not enough, autonomy needs to be functional. Similarly, creating community level institutions alone does not serve the purpose of devolution; sufficient investment needs to go simultaneously to make them effective (Ghate 2008). For this, positive and proactive intervention by various agencies is essential. 


\section{ACKNOWLEDGEMENTS}

The authors wish to acknowledge the writing fellowship given by IFRI to Rucha Ghate, which gave them an opportunity to spend a month at SNRE, University of Michigan in the summer of 2009. Rachel Kornak extended support with data extraction from the large IFRI data set, and Evanshainia Syiem helped with organisation of the data. The authors have also benefited from the comments given by Bhim Adhikari and Lauren Persha.

\section{REFERENCES}

Acheson, J. \& Gardner, R., 2004. Strategies, Conflict, and the Emergence of Territoriality: The Case of the Maine Lobster Industry. American Antbropologist, 106(2):296-307.

Adhikari, B., 2006. Forest Management and Governance in Nepal: Insights from Property Rights Theory and Policy Analysis. Environment Department: University of York, UK.

Adhikari, M., Nagata,S., \& Adhikari, M. 2003. Decentralization, Local Institutions and Forest Management in Chitwan District of Nepal, Paper Submitted to the XII World Forestry Congress, Quebec city, Canada.

Agrawal, A. \& Ostrom, E., 2001. Collective Action, Property Rights, and Decentralization in Resource Use in India and Nepal. Politics \& Society, 29 (4): 485-514.

Agrawal, A. \& Gupta, K. 2005. Decentralization and Participation: The Governance of Common Pool Resources in Nepal's Terai. World Development, 33(7):1101-14.

Anderson, J. 2000. Four Considerations for Decentralized Forest Management: Subsidiarity, Empowerment, Pluralism and Social Capital. In: Enters, T., Durst, P.B. and M. Victor (Eds.), Decentralization and Devolution of Forest Management in Asia and the Pacific, RECOFTC Report N.18 and RAP Publication 2000/1. Bangkok, Thailand.

Banana, A.,Vogt, N.D., Gombya-Ssembajjwe,W., \& Bahati.J. 2004. Local Governance and Forest Conditions: The Case of Forests in Mpigi District of Uganda, Presented at the Commons in an Age of Global Transition: Challenges, Risks and Opportunities, the Tenth Biennial Conference of the International
Association for the Study of Common, Oaxaca, Mexico, August 9-13, 2004. (Available at: http://hdl.handle.net/ 10535/1489)

Ballabh,V., Balooni,K., \& Dave, S., 2002. Why Local Resources Management Institutions Decline: A Comparative Analysis of Van (forest) Panchayat and Forest protection committees in India World Development 30(12): 2153-2167.

Burns, B. \& Burns,P. C. 2004. Collective Action and Property Rights for Sustainable Development (Strengthening collective action), 2020 Vision for Food, Agriculture, and the Environment, Focus II, Brief 15 of 16.

Esmail, T. 1997. Designing and Scaling-Up Productive Natural Resource Management Programs: Decentralization and Institutions for Collective Action, Technical Consultation Decentralization FAO, Rome, 16-18 December.

Fisher, R. J. 2000. Decentralization and Devolution in Forest Management: A Conceptual Overview', In: T. Victor, M and P. Durst (Eds.), Decentralization and Devolution of Forest Management in Asia and the Pacific, RECOFTC, Report No. 18 Bangkok, Thailand.http://www.recoftc.org/site/ index.php?id $=234$

Gautam, A., Shivakoti,G., \& Webb,E. 2004. A Review of Forest Policies, Institutions, and Changes in the Resource Condition in Nepal. International Forestry Reviem 6(2): 136-148.

Ghate, R. 2000. The role of autonomy in self-organizing processes, Working Paper W00-12, Workshop in Political Theory and Policy Analysis, Indiana University, Bloomington.

Ghate, R. 2008. Lack Of Investment In Institution Building: A Major Lacuna of JFM, Paper Presented at IASC conference, July 2008.

Ghate, R. \& Nagendra, H. 2005. Role of Monitoring in Institutional Performance: Forest Management in Maharashtra, India. Conservation and Society, 3 (2): 509-532.

Gibson, C., Dodds D., \& Turner, P. 2007. Explaining Community-Level Forest Outcomes: Salience, Scarcity and Rules in Eastern Guatemala, Conservation and Society, 5 (3), 360-381.

Gibson, C., Anderson,K., Ostrom,E., \& Shivkumar,S 2005. The Samaritan's Dilemma: The Political Economy of Development Aid, OUP, Inc. New York. 
Giri, K. \& H.R.Ojha. 2010. Enhancing Livelihoods from Community Forestry in Nepal: Can Technobureaucratic Behaviour Allow Innovation Systems to Work? International Farming Systems Associations (IFS A) proceedings. 9th European IFS A Symposium, 4-7 July 2010, Vienna Austria.

Guha, R. 1983. Forestry in British and Post-british India A Historical Analysis. Economic and Political Weekly, 8 (44): 1940-1947.

Hill, D. 2000. Assessing the Promise and Limitations of Joint Forest management in a Era of Globalisation: The Case of West Bengal, Paper Presented at the Eighth Biennial Conference of the IASCP - 'Constituting the commons: Crafting sustainable commons in the new millennium', Bloomington, Indiana University, USA, May $31^{\text {st-June }}$ 4th.

Joshi, G. 1983. Forest Policy and Tribal Development, In: W. Fernandes and S. Kulkarni (Eds.), Towards A New Forest Policy: People's Rights and Environmental Needs, Indian Social Institute, New Delhi.

Kanel, K.R. 2008. So Far So Good: Next Steps in Community Forestry. In: Ghate, Jodha and Mukhopadhyay (Eds.), Promise, Trust, and Evolution, Oxford University Press.

Kaushal, K., \& Kala, J.C. 2004. Applying the Sustainable Livelihood Approach to Joint Forest Management Projects in India. International Forestry Review, 6 (1): 13-18.

Khatri-Chhetri, A. 2008. Who Pays for Conservation: Evidence from Forestry in Nepal. In: Ghate, Jodha and Mukhopadhyay (Eds.), Promise, Trust, and Evolution, Oxford University Press.

Kumar, S. 2002. Does Participation in Common Pool Resource Management Help the Poor: A Social CostBenefit Analysis of Joint Forest Management in Jharkhand, India. WorldDevelopment, 30 (5): 763-782.

Lele, S. 2000. Godsend, Sleight of Hand, or Just Muddling Through: Joint Water And Forest Management India. Natural Resource Perspectives, ODI No. 53.

Matta, J. R. \& Karr, J. 2004. Selling Environmental Services -Challenges and Opportunities for Sustaining Local Resource Management: Lessons from Joint Forest Management experience in Tamil Nadu, India. Paper Presented at the $10^{\text {th }}$ Biennial LASCP Conference on 'The Commons in an Age of Global Transition, Challenges, Risks and Opportunities' at Oaxaca, Mexico, August.

Nayak, P. \& Berkes, F. 2008. Politics of Co-option: Community Forest Management Versus Joint Forest
Management in Orissa, India. Environmental Management, 41 (5): 707-718.

Ojha, H. 2006. Techno-bureaucratic Doxa and the Challenges of Deliberative Governance - The Case of Community Forestry Policy and Practice in Nepal. Policy and Society, 25(2): 131-175.

Ostrom, E. 1990. Governing the Commons: The Evolution of Institutions for Collective Action. New York: Cambridge University Press.

Ostrom E. 1998. Self Governance and Forest Resources, Plenary Presentation, International CBNRM Workshop, Washington D.C., USA.

Ostrom, E. 2005. Understanding Institutional Diversity. Princeton, NJ: Princeton University Press.

Ostrom, E. \& Nagendra,H. 2006. Insights on Linking Forests, Trees, and

People from the Air, on the Ground, and in the Laboratory, Proceedings of the

National Academy of Sciences, 103 (51): 19224-231.

Pokharel, B., Branney,P., Nurse,M., \& Malla,Y.B. 2007. Community forestry: Conserving Forest, Sustaining Livelihoods and Strengthening Democracy. Journal of Forest and Livelibood, 6 (2): 8-19

Pokharel, R. K. 2008. Nepal's Community Forestry Funds: Do They Benefit the Poor? SANDEE Working Pape No. 31-08.

Puri, E. 2004. Understanding Participation: Theoretical Foundations and Practical Implications. Economic and Political Weekly, 39 (24): 2511-2517.

Regmi, A. 2008. Self-Governance in Farmer Managed Irrigation Systems in Nepal. Journal of Developments in Sustainable Agriculture, 3: 20-27.

Sarin, M., Singh, N.M., Sundar,N., \& Bhogal,R. K. 2003. Devolution as a Threat to Democratic Decision-Making in Forestry? Findings from Three States in India. Working Paper 197. Overseas Development Institute, London, U.K.

Shiva, V., Sharatchandra,H.C., \& Bandopadhyay,J. 1983. The Challenge of Social Forestry In. W. Fernandes and S. Kulkarni (Eds.), Towards A New Forest Policy: People's Rights and Environmental Needs, Indian Social Institute, N. Delhi.

Upadhyay, S. 2003. JFM in India: Some Legal Concerns, Economic and Political Weekly, 38 (35): 3629-3631. 


\section{Appendix : 1}

Scores of various indices representing autonomy, institutional functioning and forest dependence

\begin{tabular}{|l|l|l|l|l|l|}
\hline Site name and visit & $\begin{array}{c}\text { Autonomy } \\
\text { index }\end{array}$ & $\begin{array}{c}\text { Management } \\
\text { index }\end{array}$ & $\begin{array}{c}\text { Rule } \\
\text { index }\end{array}$ & $\begin{array}{c}\text { Participation } \\
\text { index }\end{array}$ & $\begin{array}{c}\text { Forest } \\
\text { dependence } \\
\text { index }\end{array}$ \\
\hline Raniswara (first visit) & 5 & 9 & 6 & 6 & 41.25 \\
Raniswara (Second visit) & 5 & 16 & 6 & 7 & 32.5 \\
Barbote (first visit) & 4 & 7 & 5 & 4 & 25 \\
Barbote (Second visit) & 4 & 4 & 6 & 5 & 30 \\
Khareha (first visit) & 5 & 4 & 6 & 4 & 40 \\
Khareha (Second visit) & 4 & 13 & 6 & 5 & 45 \\
Danapur (first visit) & 4 & 4 & 6 & 5 & 22.5 \\
Danapur (Second visit) & 6 & 4 & 5 & 6 & 50 \\
Chandraban (first visit) & 3 & 4 & 6 & 4 & 52.5 \\
Chandraban (Second visit) & 5 & 7 & 5 & 6 & 53.75 \\
Thoplebiran (first visit) & 4 & 4 & 6 & 6 & 52.5 \\
Thoplebiran (Second visit) & 5 & 9 & 6 & 8 & 52.5 \\
Saigata (first visit) & 4 & 4 & 6 & 5 & 77.5 \\
Saigata (Second visit) & 3 & 6 & 6 & 6 & 75 \\
Lakhapur (first visit) & 3 & 15 & 5 & 4 & 25 \\
Lakhapur (Second visit) & 3 & 8 & 6 & 5 & 72.5 \\
Mendha (first visit) & 3 & 11 & 6 & 6 & 77.5 \\
Mendha (Second visit) & 3 & 10 & 6 & 6 & 77.5 \\
Markegaon (first visit) & 3 & 4 & 4 & 6 & 80 \\
Markegaon & 3 & 3 & 6 & 6 & 80 \\
Deulgaon (first visit) & 2 & 3 & 6 & 6 & 80 \\
Deulgaon & 4 & 6 & 4 & 77.5 \\
Ranvahi (first visit) & 3 & 4 & 6 & 5 & 75 \\
Ranvahi (Second visit) & 2 & 4 & 5 & 5 & 76.25 \\
Maximum possible scores & 06 & 19 & 06 & 09 & 100 \\
Apand : & & & & \\
\hline
\end{tabular}

Appendix : 2

Forest quality indicators

\begin{tabular}{|l|l|l|c|c|c|}
\hline Site name and visit & Basal area & $\begin{array}{c}\text { Simpson } \\
\text { diversity index }\end{array}$ & $\begin{array}{c}\text { Number } \\
\text { of Species } \\
\text { lost in } \\
\text { past 5 } \\
\text { years }\end{array}$ & $\begin{array}{c}\text { Number } \\
\text { of Species } \\
\text { lost in past } \\
\text { 10 years }\end{array}$ & $\begin{array}{c}\text { Percentage } \\
\text { of plots } \\
\text { with } \\
\text { erosion }\end{array}$ \\
\hline Raniswara (first visit) & 19.56 & .45 & 0 & 0 & 2 \\
Raniswara (Second visit) & 12 & .54 & 0 & 0 & 0 \\
Barbote (first visit) & 20.75 & .22 & 0 & 0 & 0 \\
Barbote (Second visit) & 28.94 & .20 & 0 & 0 & 0 \\
\hline
\end{tabular}




\begin{tabular}{|l|l|l|l|c|c|}
\hline Site name and visit & Basal area & $\begin{array}{c}\text { Simpson } \\
\text { diversity index }\end{array}$ & $\begin{array}{c}\text { Number } \\
\text { of Species } \\
\text { lost in } \\
\text { past 5 } \\
\text { years }\end{array}$ & $\begin{array}{c}\text { Number } \\
\text { of Species } \\
\text { lost in past } \\
\text { 10 years }\end{array}$ & $\begin{array}{c}\text { Percentage } \\
\text { of plots } \\
\text { with } \\
\text { erosion }\end{array}$ \\
\hline Khareha (first visit) & 2.7 & .63 & 0 & 0 & 3 \\
Khareha (Second visit) & 17.26 & .61 & 0 & 0 & 0 \\
Danapur (first visit) & 8.52 & .17 & 0 & 0 & 0 \\
Danapur (Second visit) & 6.92 & .19 & 0 & 0 & 0 \\
Chandraban (first visit) & 9.08 & .81 & 0 & 0 & 0 \\
Chandraban (Second visit) & 9.89 & .74 & 0 & 0 & 0 \\
Thoplebiran (first visit) & 23.77 & .15 & 0 & 0 & 0 \\
Thoplebiran (Second visit) & 13.92 & .12 & 0 & 0 & 0 \\
Saigata (first visit) & 2.51 & .08 & 0 & 0 & 0 \\
Saigata (Second visit) & 3.54 & .11 & 0 & 0 & 90 \\
Lakhapur (first visit) & 2.89 & .13 & 0 & 0 & 0 \\
Lakhapur (Second visit) & 3.28 & .18 & 0 & 0 & 83 \\
Mendha (first visit) & 20.98 & .11 & 0 & 0 & 0 \\
Mendha(Second visit) & 19.47 & .11 & 0 & 0 & 87 \\
Markegaon (first visit) & 21.15 & .07 & 1 & 5 & 16 \\
Markegaon (Second visit) & 17.14 & .09 & 1 & 2 & 100 \\
Deulgaon (first visit) & 16.78 & .09 & 0 & 0 & 3 \\
Deulgaon (Second visit) & 15.97 & .08 & 1 & 1 & 77 \\
Ranvahi (first visit) & 15.76 & .13 & 0 & 0 & 13 \\
Ranvahi (Second visit) & 13.26 & .08 & 0 & 0 & 80 \\
\hline
\end{tabular}

\section{Appendix : 3}

Regression of autonomy index over country and visits

\begin{tabular}{|l|l|l|l|l|}
\hline Variable & Unstandardized coefficients & & & \\
\hline & $\mathrm{B}$ & Std. Error & $\mathrm{T}$ & Sig \\
\hline C(Constant) & 3.00 & .284 & 10.570 & .000 \\
\hline Country & 1.167 & .401 & 2.907 & .009 \\
\hline Visit & $4.66 \mathrm{E}-016$ & .401 & .000 & 1.000 \\
\hline Covis & .667 & .568 & 1.174 & .254 \\
\hline
\end{tabular}

Dependent variable: Autonomy index, $\mathrm{R}=.778, \mathrm{R}^{2}=.605$, country -0 (India), country -1 (Nepal); visit -

0 (first visit), visit -1 (revisit); covis - country $\mathrm{x}$ visit

\section{Appendix : 4}

Regression of forest dependence over country and visits

\begin{tabular}{|l|l|l|l|l|}
\hline Variable & Unstandardized coefficients & & & \\
\hline & $\mathrm{B}$ & Std. Error & $\mathrm{T}$ & Sig \\
\hline C(Constant) & 69.167 & 5.599 & 12.353 & .000 \\
\hline Country & $-3-.208$ & 7.919 & -3.815 & .001 \\
\hline Visit & 7.292 & 7.919 & .921 & .368 \\
\hline Covis & -2.292 & 11.199 & -.205 & .840 \\
\hline
\end{tabular}

Dependent variable: forest dependence; $\mathrm{R}=-.787, \mathrm{R}^{2}=.62$; country -0 (India), country -1 (Nepal); visit -0 (first visit), visit -1 (revisit); covis - country $\mathrm{x}$ visit 